\title{
A spectrophotometric micro determination of pyridoxine hydrochloride by coupling diazometry
}

M .S . Saleem

Chemistry Department / College of Education

Mosul University

\author{
Z .A .Mohammed
}

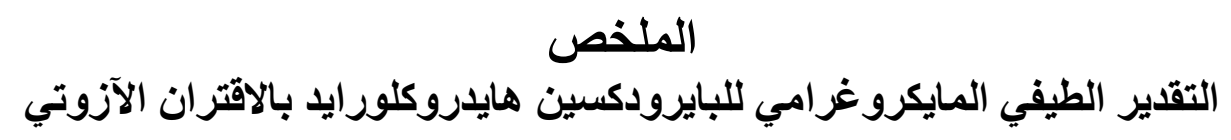

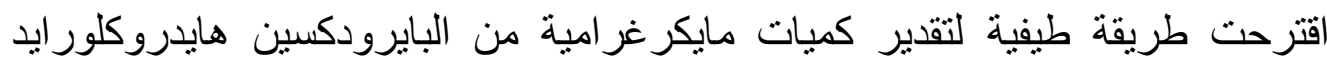

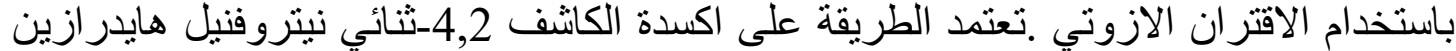

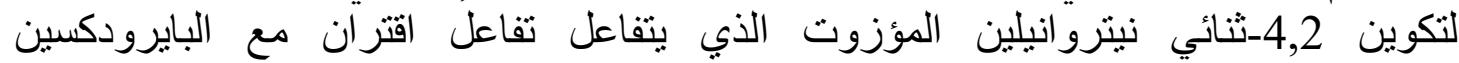

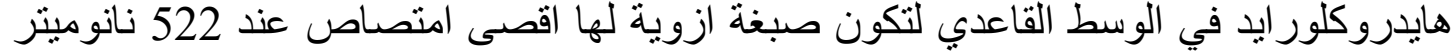

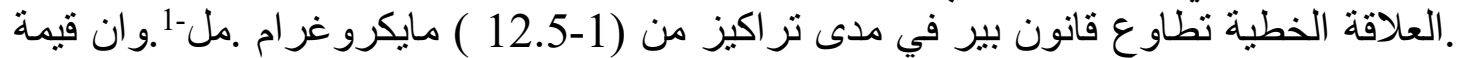

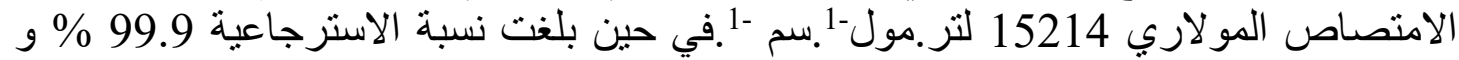

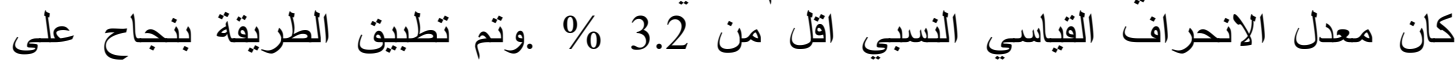

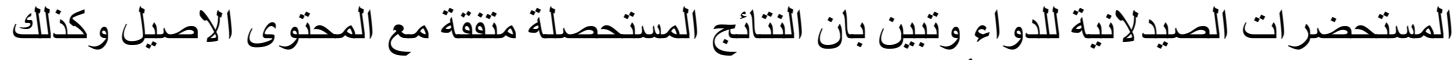
مع طريقة الدستور البريطاني للأدوية .

\section{ABSTRACT}

A simple, rapid and sensitive spectrophotometric method has been investigated for determination of microgram amount of pyridoxine hydrochloride .The method is based on the oxidation of 2,4dinitrophenylhydrazine to produce diazotized2,4-dinitroaniline which will be coupled with pyridoxine hydrochloride in basic medium to form a stable colored product with maximum absorption at $522 \mathrm{~nm}$. Beer'slaw is obeyed over the concentration range of 1-12.5 $\mu \mathrm{g} \cdot \mathrm{ml}^{-1}$.The molar absorptivity value is $15214 \mathrm{~L} \cdot \mathrm{mol}^{-1} \cdot \mathrm{cm}^{-1}$. The average recovery is $99.09 \%$ and relative standard deviation (RSD)is less than 3.2\%.The method has been applied successfully for the determination of the studied drug in its pharmaceutical preparation. The obtained result are in agreement with certified value of the pharmaceutical and with the British pharmacopeia method .

Keywords : pyridoxine hydrochloride , spectrophotometry , diazodization, determination

Presented at the second conference on Chemistry, University of Mosul, college of Education, 17-18 Novamber-2013. 


\section{Introduction}

Pyridoxine is (3-hydroxy-4,5-bis(hydroxymethyl)-2-methyl pyridine) which is calledvitamins B6 are white crystals at room temperature. Each is very soluble in water, weakly soluble in ethanol, and either insoluble or sparingly soluble in chloroform. Pyridoxine has chemical formula $\mathrm{C}_{8} \mathrm{H}_{11} \mathrm{NO}_{3} \cdot \mathrm{HCl}$ and posses the following chemical formula $^{(1)}$.<smiles>Cc1ncc(CO)c(CO)c1O</smiles>

The biologically active analogs of pyridoxine are the aldehyde pyridoxal and the aminepyridoxamine ${ }^{(2)}$. Pyridoxine is used to treat or prevent vitamin B6 deficiency. It is also used to treat a certain type of anemia (lack of red blood cells) ${ }^{(2)}$.Pyridoxine injection is used to treat some types of seizure in babies.Vitamins in general, play a very important role in our health, even thoughthey only make up a very small part of the food we eat each day ${ }^{(3)}$.

Sevral analytical methods are available in the literature for the determination of pyridoxine in their pharmaceutical preparations including : HPLC ${ }^{(4-8)}$, reversed phase ion-pair HPLC ${ }^{(9)}$, capillary electrophoresis ${ }^{(10)}$, cyclic voltammetry ${ }^{(11,12)}$, flow injection analysis ${ }^{(13,14)}$ and spectrophotometric methods ${ }^{(15)}$. Another spectrophotometric methods including derivative spectrophotometry with different $\operatorname{order}^{(16,17)}$, spectrofluorometry ${ }^{(18)}$, oxidative coupling reaction ${ }^{(19)}$ and coupling diazometry ${ }^{(20-23)}$.

In this work a simple spectrophotometric method for the determination of pyridoxine hydrochloride is proposed, the method is based on the oxidation of 2,4-dinitrophenyl hydrazine with potassium iodate to produce diazotized 2,4-dinitroaniline as an intermediate product which later will be coupled with pyridoxine hydrochloride to produce an intense red azo dye .

\section{Apparatus :}

\section{Experimental}

All spectral and absorbance measurements are carried out by using a Shimadzu UV- 1650 PC UV-Spectrophotometer with $1 \mathrm{~cm}$ matched silica cells .

\section{Chemicals and standard reagents:}

All chemicals used are of analytical reagent grade and are purchased from Fluka and BDH companies . pyridoxine hydrochloride $\left(100 \mu \mathrm{g} \cdot \mathrm{ml}^{-1}\right)$ solution : 
$0.01 \mathrm{~g}$ of the pure drug is accurately weight and dissolved in distilled water in a $100 \mathrm{ml}$ volumetric flask and diluted to mark with the same solvent .

2,4-Dinitrophenylhydrazine $(0.04 \%)$ solution (DNPH) :

Is prepared by dissolving $0.04 \mathrm{~g}$ of DNPH in $1 \mathrm{ml}$ concentrated sulphuric acid and completed to the mark with acetonitrile in a $100 \mathrm{ml}$ volumetric flask .

Potassium iodate (4\%) solution :

$4 \mathrm{~g}$ of this compound is dissolved in $75 \mathrm{ml}$ of distilled water with heating and the volume is made to the mark with distilled water in a 100 $\mathrm{ml}$ volumetric flask .

Sodium hydroxide $(1 \mathrm{M})$ solution :

$4 \mathrm{~g}$ is accurately weighed and dissolved in distilled water and completed to $100 \mathrm{ml}$ with same solvent .

Surfactant $0.1 \%$ and $1 \%$ solution :

This solution is prepared by dissolving, $0.1 \mathrm{~g}$ of cetyltrimethylammonium bromide (CTAB) and sodium dodecyl sulphate (SDS) , $1 \mathrm{~g}$ of Tritone-x 100 and Tween-80 in distilled water and the solutions will be completed to $100 \mathrm{ml}$ with the same solvent .

Interference $\left(1000 \mu \mathrm{g} \cdot \mathrm{ml}^{-1}\right)$ :

This solution is prepared by dissolving $0.1 \mathrm{~g}$ of each compound to $100 \mathrm{ml}$ with distilled water.

\section{Recommended procedure}

To a series of $10 \mathrm{ml}$ volumetric flasks different amounts of pyridoxine hydrochloride stock standard solution are added to cover the concentration range $\left(1-12.5 \mu \mathrm{g} \cdot \mathrm{ml}^{-1}\right)$ followed by the addition of $0.04 \%$ $\mathrm{DNPH}, 1.5 \mathrm{ml}$ of oxidant $\left(\mathrm{KIO}_{3}\right)$ reagent and $2 \mathrm{ml}$ of $1 \mathrm{~N} \mathrm{NaOH}$. The volume is completed to the mark with distilled water. The absorbance of solutions are measured versus blank reagent at $522 \mathrm{~nm}$. after 5 minutes from dye production .

\section{Procedure for the determination of pyridoxine hydrochloride in its pharmaceutical preparation . Preparation of pyridoxine hydrochloride tablet solution :}

Five tablets of each of the two types of pyridoxine tablets are weighed then powdered and mixted thoroughly. A quantity equivalent to one tablet weight is dissolved in distilled water and filtered and the volume is made up to the mark with distilled water in a $100 \mathrm{ml}$ volumetric flask to prepare $400 \mu \mathrm{g} \cdot \mathrm{ml}^{-1}$. A $100 \mu \mathrm{g} \cdot \mathrm{ml}^{-1}$ solution is prepared by further dilution of the solution . A suitable aliquot is treated as described under the recommended procedure . 


\section{Preparation of pyridoxine ampoules solution :}

An accurately $2 \mathrm{ml}$ containing $100 \mathrm{mg}$ of pyridoxine drug is transferred to a $100 \mathrm{ml}$ volumetric flask and the volume is completed to the mark with distilled water and mixed well and is further diluted to get the working standard solution with distilled water. A suitable aliquot is treated as described under the recommended procedure .

\section{Results and Discussion}

It has been shown recently ${ }^{(24)}$ that 2,4-dinitrophenylhydrazine can be oxidized by potassium iodate or sodium periodate to diazotized 2,4dinitroanilineas an intermediate compound which latercan be coupled with pyridoxine hydrochloride in basic medium to give red azo dye that shows an absorption maxima at the wavelength of $522 \mathrm{~nm}$ (Fig 1). The suggested reaction can be represented as follow :<smiles>N#[N+]c1ccc([N+](=O)[O-])cc1[N+](=O)[O-]</smiles>
$2,4-$<smiles>Cc1ncc(CO[Hg]Cl)c(CO)c1O</smiles>

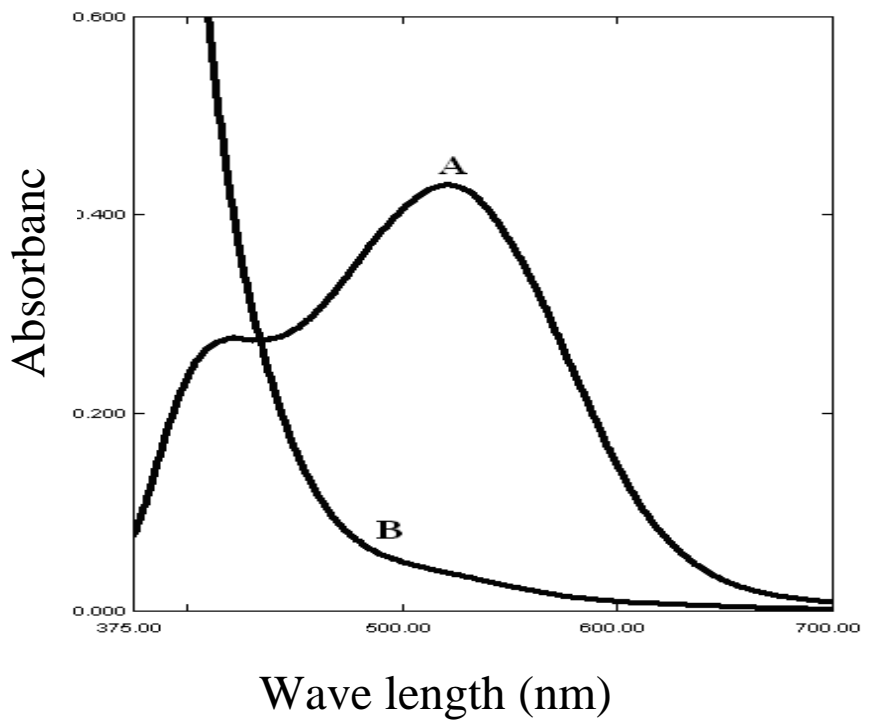

Fig.1 : Absoption spectra of $6 \mu \mathrm{g} \cdot \mathrm{ml}^{-1}$ of pyridoxine hydrochloride .

A : Sample vs blank B: Reagentblank vs distilled water . 


\section{Study of the optimum reaction conditions .}

The effect of various parameters on the absorption intensity of the formed azo dye formed have been studied and the reaction conditions are optimized .

\section{Effect of organic solvent :}

Preliminary investigation shows that the preparation of the solution of 2,4-dinitrophenylhydrazine reagent in organic solvent is more perfeable for giving high azo dye colour intensity therefore the preparation of the reagent in different solvents are studied (Table 1) From table. 1 itis shown that acetonitrile gives the highest colour intensity of the dye .

Table.1 : Effect of organic solvents on azo dye absorbance .

\begin{tabular}{|c|c|c|c|}
\hline Solvent & $\lambda_{\max }$ & Absorbance & $\begin{array}{c}\text { Molar absorptivity } \\
\left(\mathrm{L} \cdot \mathrm{mol}^{-1} \cdot \mathrm{cm}^{-1}\right)\end{array}$ \\
\hline \hline Ethanol & 481 & 0.269 & 11061.31 \\
\hline Methanol & 534.5 & 0.287 & 11801.47 \\
\hline Acetone & 517.5 & 0.348 & 14309.79 \\
\hline Acetonitrile & 522 & 0.420 & 15200.44 \\
\hline DMSO & 524.5 & 0.136 & 5592.33 \\
\hline Water & 542 & 0.281 & 11554.75 \\
\hline
\end{tabular}

\section{Effect of DNPH :}

The effect of the amounts of $0.04 \%$ DNPH which will be oxidized further to diazotized 2,4-dinitroaniline that will couple pyridoxine drug to form an intense red azo dye are studied to show their effects on the absorbance intensity .

The experimental results in table. 2 indicated that $2 \mathrm{ml}$ of $0.04 \%$ of DNPH gives the highest colour intensity therefore it is considered as an optimum value for further studies .

Table.2 : Effect of reagent amounts on dye absorbance .

\begin{tabular}{|c|c|}
\hline $\mathrm{ml}$ of DNPH $0.04 \%$ & Absorbance \\
\hline \hline 0.5 & 0.24 \\
\hline 1.0 & 0.40 \\
\hline 1.5 & 0.41 \\
\hline 2.0 & 0.43 \\
\hline 2.5 & 0.39 \\
\hline 3.0 & 0.39 \\
\hline
\end{tabular}




\section{Effect of type of oxidant :}

In order to choice the best oxidant reagent, a $1 \mathrm{ml}$ of $0.4 \%$ of each of different type oxidants except $\mathrm{N}$-bromosuccinimide $(0.2 \%)$ is added to $2 \mathrm{ml}$ of $0.04 \%$ of $\mathrm{DNPH}$ with $0.5 \mathrm{ml}$ of $100 \mu \mathrm{g} \cdot \mathrm{ml}^{-1}$ pyridoxine hydrochloride and followed with $2 \mathrm{ml}$ of $1 \mathrm{~N} \mathrm{NaOH}$. The results given in table.3 show that potassium iodate gives the highest sensitivity of the formed dye, however it is used as the best oxidant for the oxidation process .

A further study revels that $1.5 \mathrm{ml}$ of $0.4 \% \mathrm{KIO}_{3}$ is an optimum amount that will be used for subsequent work (Table.4) .

Table . 3 : Effect of oxidant type on dye intensity

\begin{tabular}{|c|c|}
\hline Oxidizing agent $4 \%$ & Absorbance \\
\hline Sodium Periodate & 0.25 \\
\hline Potassium Poriadate & 0.40 \\
\hline Potassium Iodate & 0.42 \\
\hline N- Bromosuccinimde & 0.01 \\
\hline Potassium Dichromate & 0.06 \\
\hline Ammonium Persulphonate & 0.02 \\
\hline
\end{tabular}

Table.4 : Effect oxidant amount on the absorbance.

\begin{tabular}{|c|c|}
\hline ml of $4 \% \mathrm{KIO}_{3}$ & Absorbance \\
\hline \hline 0.5 & 0.38 \\
\hline 1.0 & 0.41 \\
\hline 1.5 & 0.43 \\
\hline 2.0 & 0.32 \\
\hline 2.5 & 0.27 \\
\hline 3.0 & 0.30 \\
\hline
\end{tabular}

\section{Effect of surfactant:}

The presence of surfactants in coloured mixture solution may frequently leads to a bathochromic red shift ${ }^{(25)}$. In thisrespect a different types of surfactant including (CTAB) $0.1 \%$ (cationic) , (SDS) $0.1 \%$ (anionic), Triton x-100 1\% and Tween-80 1\% (nonionic) have been tested .

Unfortunately none of them improve the absorption therefore they were excluded from this study . 


\section{Effect of base :}

It has been observed previously that most azo dyes are only formed in alkaline basic medium, therefore a different amount of $1 \mathrm{~N}$ of various bases have been tried for the purpose of producing the more intense dye colour. The results in table. 5 express that $2 \mathrm{ml}$ of $1 \mathrm{~N}$ sodium hydroxide gives the highest colour sensitivity and as result it is considered as an optimum value of the amount of the best base can be used for subsequent research .

Table.5 : Effect of amounts and base type on absorbance of the formed azo dye .

\begin{tabular}{|l|c|c|c|c|c||}
\hline \multirow{2}{*}{$\begin{array}{l}\text { Base solution } \\
\text { used (IN) }\end{array}$} & \multicolumn{5}{|c|}{ Absorbance / ml of base used } \\
\cline { 2 - 6 } & 1.0 & 1.5 & 2.0 & 2.5 & 3.0 \\
\hline \hline $\mathrm{NaOH}$ & 0.30 & 0.40 & 0.42 & 0.40 & 0.33 \\
\hline $\mathrm{KOH}$ & 0.35 & 0.40 & 0.40 & 0.38 & 0.30 \\
\hline $\mathrm{Na}_{2} \mathrm{CO}_{3}$ & 0.01 & 0.02 & 0.25 & 0.26 & 0.26 \\
\hline $\mathrm{NaHCO}_{3}$ & 0.03 & 0.22 & 0.22 & 0.23 & 0.22 \\
\hline $\mathrm{NH}_{4} \mathrm{OH}$ & 0.01 & 0.01 & 0.01 & 0.01 & 0.01 \\
\hline
\end{tabular}

\section{Effect of order of addition :}

The effective of order of addition on the absorbance of formed azo dye is tested under the optimum experimental conditions and the resulted data indicate that the azo dye formed with highest sensitivity by the following sequence :

DNPH reagent + oxidizing agent + drug sample + base

\section{Effect of temperature and reaction time :}

The reaction time is determined by following the produced azo dye colour development at $0 \mathrm{C}^{\mathrm{o}}$, room temperature and thermostatically controlled water-bath at 40 and $50 \mathrm{C}^{\circ}$ (Table.6). It has been observed the absorbance reaches it's maximum value after 5 minutes at room temperature and remain constant for more than one hour at room temperature, therefore a 5 minutes as a development time at room temperature is selected for subsequent studies .

Table.6 Effect of temperature and time on colour stability .

\begin{tabular}{|c|c|c|c|c|}
\hline \multirow{2}{*}{$\begin{array}{c}\text { Standing } \\
\text { Time(min) }\end{array}$} & \multicolumn{4}{|c|}{ Absorbance / Temperature ${ }^{\circ} \mathrm{C}$} \\
\cline { 2 - 5 } & 0.0 & Room Temp. $*$ & 40 & 50 \\
\hline \hline After addition & 0.20 & 0.40 & 0.40 & 0.20 \\
\hline 5 & 0.17 & 0.44 & 0.42 & 0.18 \\
\hline 10 & 0.20 & 0.44 & 0.38 & 0.14 \\
\hline 15 & 0.26 & 0.44 & 0.43 & 0.28 \\
\hline 20 & 0.27 & 0.44 & 0.41 & 0.30 \\
\hline 25 & 0.37 & 0.44 & 0.40 & 0.26 \\
\hline 30 & 0.34 & 0.44 & 0.34 & 0.27 \\
\hline 40 & 0.37 & 0.44 & 0.39 & 0.31 \\
\hline 50 & 0.36 & 0.44 & 0.39 & 0.25 \\
\hline 60 & 0.38 & 0.44 & 0.41 & 0.23 \\
\hline 75 & 0.37 & 0.44 & 0.39 & 0.23 \\
\hline
\end{tabular}

$*$ Room Temp. $=13{ }^{\circ} \mathrm{C}$ 


\section{Quantitation and analytical data}

Employing the optimum conditions described under recommended procedure a linear calibration graph (Figure.2) for pyridoxine hydrochloride is obtained which comprises that Beer's law is obeyed over the concentration range $1-12.5 \mu \mathrm{g} \cdot \mathrm{ml}^{-1}$ with a correlation coefficient of 0.9992 and intercept of 0.074 . The apparent molar absorptivity of the formed red azo dye is $15214.4 \mathrm{~L} \cdot \mathrm{mol}^{-1} \cdot \mathrm{cm}^{-1}$ with Sandell sensitivity of $0.0135 \mu \mathrm{g} . \mathrm{cm}^{-2}$, limit of detection 0.0355 and limit of quantitation of $0.118 \mu \mathrm{g} \cdot \mathrm{ml}^{-1}$ respectively .

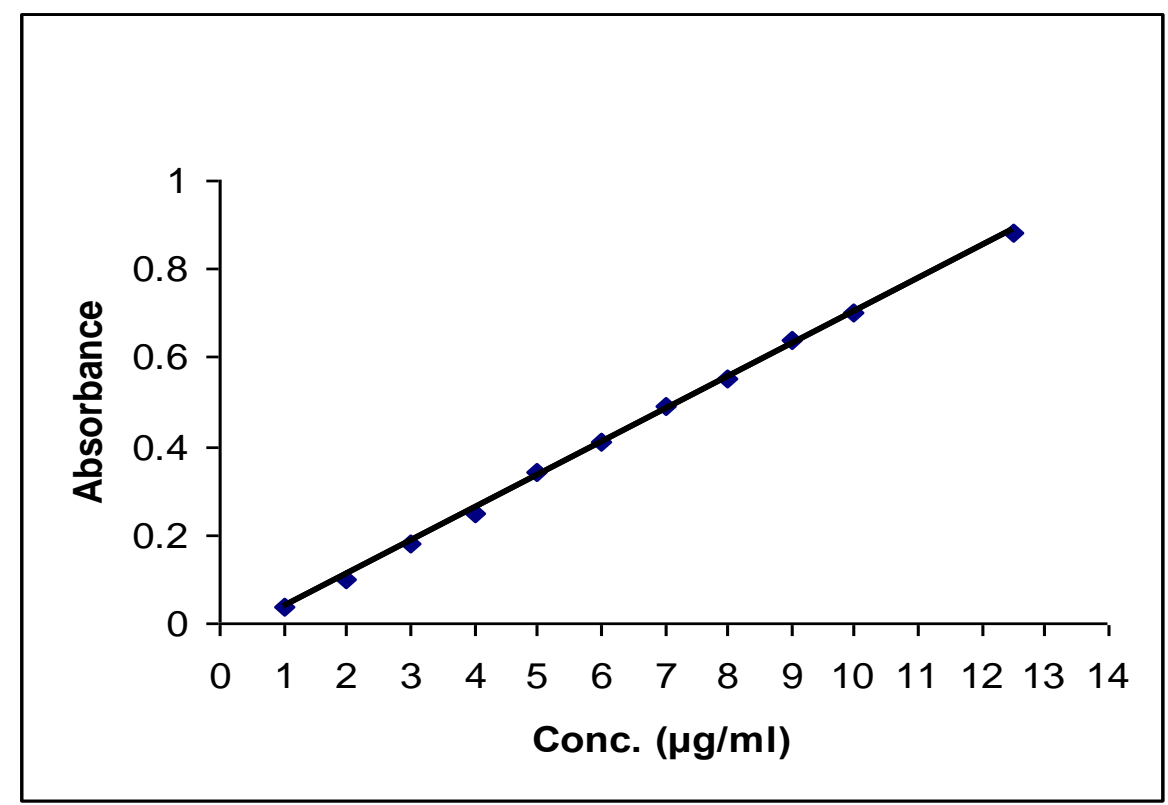

Figure.2 : calibration graph of pyridoxine hydrochloride .

\section{Accuracy and precision :}

To evaluate the accuracy and precision of the proposed method, a pure drug is analyzed at three different concentration. The observed data shown in table.7 comprise a satisfactory precision and accuracy for the proposed method .

Table.7 : Accuracy and precision .

\begin{tabular}{|c|c|c|c|}
\hline Conc. of pyridoxine. $\mathrm{HCl} \mu \mathrm{g} / \mathrm{ml}$ & Recovery *\% & $\begin{array}{l}\text { Average of } \\
\text { Recovery \% }\end{array}$ & RSD* \% \\
\hline 3 & 97.77 & \multirow{3}{*}{99.09} & 3.13 \\
\hline 6 & 99.51 & & 2.05 \\
\hline 9 & 100.00 & & 1.56 \\
\hline
\end{tabular}

* For Five Determinations. 


\section{Interferences :}

To demonstrate the selectivity of the proposed method, the interfering effect of various excipients that may be accompanied the pharmaceutical products of pyridoxine hydrochloride are tested by determining $100 \mu \mathrm{g}$ of pyridoxine hydrochloride in the presence of different amount of each excipients . The results obtained are summarized in table. 8 indicated that non of the excipients can introduce significant interference .

Table.8 : Effect of excipients on azo dye colour intensity .

\begin{tabular}{|c|c|c|c|c|}
\hline \multirow{2}{*}{$\begin{array}{c}\text { Foreign } \\
\text { compound }\end{array}$} & \multicolumn{4}{|c|}{$\begin{array}{l}\text { Recovery \% of } 100 \mu \mathrm{g} \text { of Pyridoxine. HCl per } \mu \mathrm{g} \\
\text { foreign compound added }\end{array}$} \\
\cline { 2 - 5 } & 500 & 1000 & 3000 & 5000 \\
\hline Acacia & 101.28 & 102.56 & 100.00 & 101.28 \\
\hline Glucose & 101.28 & 101.28 & 97.43 & 96.15 \\
\hline Sucrose & 100.00 & 102.85 & 101.42 & 98.57 \\
\hline Glycerin & 102.94 & 98.52 & 100.00 & 101.57 \\
\hline Lactose & 101.47 & 97.05 & 98.52 & 101.47 \\
\hline NaCl & 100.00 & 98.57 & 98.57 & 101.42 \\
\hline Starch & 101.28 & 100.00 & 98.71 & 98.71 \\
\hline
\end{tabular}

\section{Structure of the dye :}

The stoichiometry of the coupling reaction between diazotized 2,4-dinitroaniline and pyridoxine hydrochloride is investigated using both Job's and mole ratio method ${ }^{(26)}$.

The obtained results in Fifure. 3 demonstrates that a ratio of drug to diazotized reagent 1:1 formed, therefore the formation of the dye probably occur as follows :<smiles>Cc1nc(N=Nc2ccc([N+](=O)[O-])cc2[N+](=O)[O-])c(CO)c(CO)c1O</smiles>

\section{Red azo dye}


The apparent stability constant ${ }^{(27)}$ is calculated to be $2.8 \times 10^{4} \mathrm{~L} \cdot \mathrm{mol}^{-1}$ as an average conditional stability constant for the drug in water under the optimized described experimental conditions .

\section{Figure.3 : A:Job's plot B:mole ratio plot}

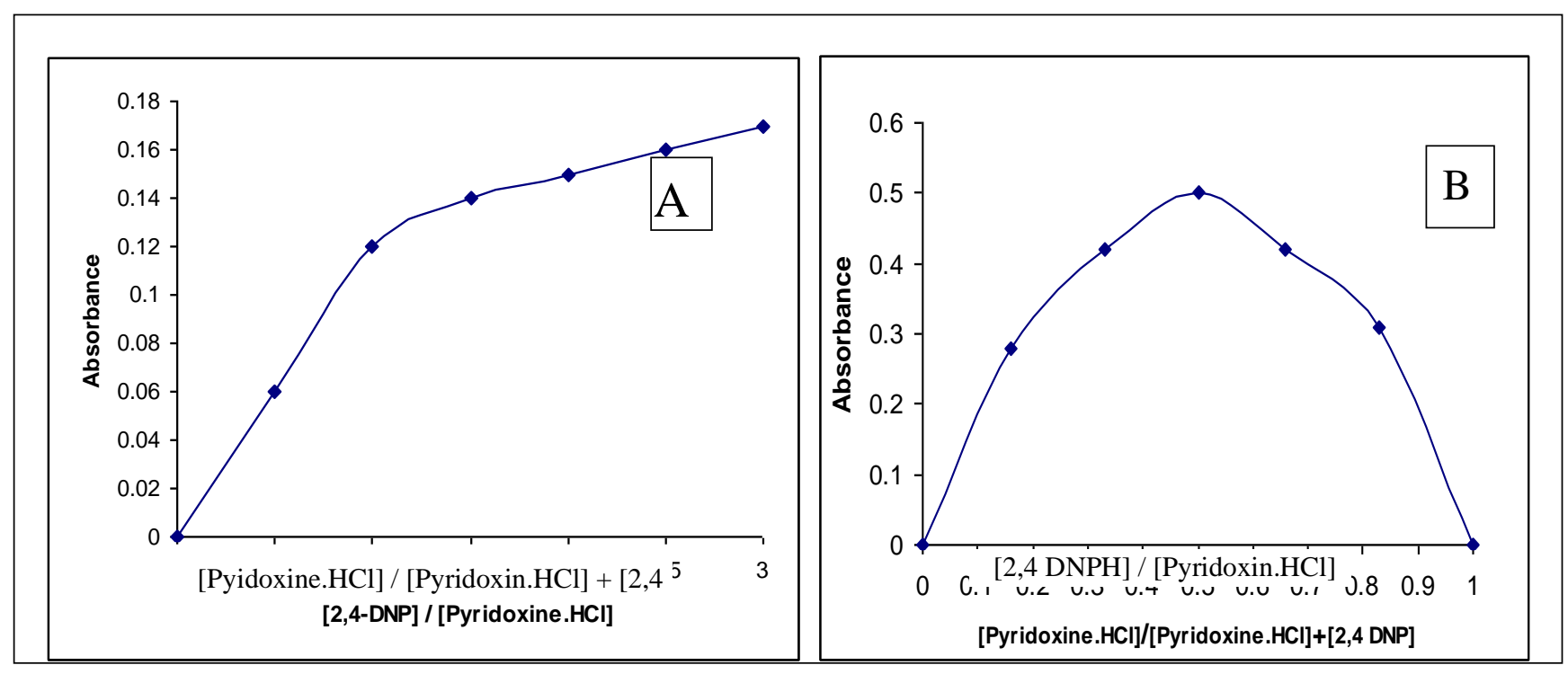

\section{Analytical Application}

Application of the proposed method for the assay of various pharmaceutical preparation of pyridoxine hydrochloride (tablet and injection) give reproducible result that revels that there is a good agreement between the proposed method and the certified value of the drug (Table.9) . The results are also compared successfully with official method (Table.10) ${ }^{(1)}$.

Table.9 : Determination of pyridoxine in its pharmaceutical preparation .

\begin{tabular}{|c|c|c|c|}
\hline Pharmaceutical Preparation & $\begin{array}{c}\text { Amount present } \\
(\mu \mathrm{g} / \mathrm{ml})\end{array}$ & $\begin{array}{c}\text { Drug content } \\
\text { found }(\mathrm{mg})\end{array}$ & Recovery (\%) \\
\hline \hline Samavit B6 tablets & 3 & 39.22 & 98.06 \\
\cline { 2 - 4 } 40 mg pyridoxine. Hcl & 6 & 39.46 & 98.67 \\
\cline { 2 - 4 } S.D.I. - Iraq & 9 & 39.51 & 98.78 \\
\hline Samavit B6 tablets & 3 & 39.61 & 99.03 \\
\cline { 2 - 4 } 40 mg pyridoxine. Hcl & 6 & 39.39 & 98.48 \\
\cline { 2 - 4 } N.D.I. - Iraq & 9 & 39.39 & 98.48 \\
\hline Pyridoxine. Hcl injection & 3 & 99.67 & 99.67 \\
\cline { 2 - 4 } 100 mg/2ml pyridoxine. HCl & 6 & 98.11 & 98.11 \\
\cline { 2 - 4 } Milano - Italy & 9 & 99.29 & 99.29 \\
\hline
\end{tabular}


Table.10 : Determination of pyridoxine hydrochloride in pharmaceutical preparation by proposed method and official method .

\begin{tabular}{|c|c|c|c|c|}
\hline \multirow{2}{*}{$\begin{array}{c}\text { Parmaceutical } \\
\text { preparation }\end{array}$} & $\begin{array}{c}\text { Certified } \\
\text { value }\end{array}$ & $\mathrm{mg}$ & $\begin{array}{c}\text { Present } \\
\text { method }\end{array}$ & $\begin{array}{c}\text { Standard } \\
\text { method }\end{array}$ \\
\cline { 3 - 5 } & $40 \mathrm{mg}$ & 10 & 99.65 & 98.86 \\
\hline Samavit B6 tablets & 100 & 2 & 99.32 & 98.18 \\
\hline $\begin{array}{c}\text { Pyridoxine. HCl } \\
\text { injection }\end{array}$ & $\mathrm{mg} / 2 \mathrm{ml}$ & 4 & 99.86 & 99.01 \\
\hline
\end{tabular}

*Average of three determinations.

The performance of the proposed method is compared statistically in terms of student t-test and the variance ratio F-test . At $95 \%$ confidence level, the calculated $t$ value is 2.04 and $F$-value is 2.435 and these value do not exceed the tabulated $\mathrm{t}$-value is 2.31 (for $\mathrm{n}=8$ ) and $\mathrm{F}$-value is 6.39 (for $n=4$ ). Therefore there is no significant difference between the propose method and the official method, indicating that the proposed method is as . accurate and precise as official method .

\section{Conclusion}

A simple, rapid and sensitive spectrophotometric method for the determination of trace amounts of pyridoxine hydrochloride in aqueous solution has been developed .

The proposed method requires neither temperature control nor solvent extraction and can satisfactorily be applied without modification to the analysis of pyridoxine hydrochloride in pharmaceutical preparation .

\section{Reference}

1. "British pharmacopoeia", (2007), Vol. I \& II, HM Stationary Office, London, p. 1151, 1411, 1600, 1147.

2. Gerald F. Combs, Jr., Ph.D.(2008)"The Vitamins Fundamental Aspects in Nutrition and Health " $3^{\text {rd }}$, Elsevier Academic Press, London Uk,p56.

3. L. L. Brunton, J. S. Lazo and K. L. Parker (2006), "The Pharmacological Basis of Therepeutics", McGraw-Hill, London, $11^{\text {th }}$ ed., p. 404-1119.

4. A. P. Argekar, J. G. Sawant (1999), "Simultaneous determination of pyridoxine hydrochloride and doxylamine succinate in tablets by HPTLC', J. Liquid Chromatogr. \& Related Technologies, 22, 2051-2060. 
5. E. Kompantseva, A. Khalate, L. Ovcharenko, L. Dukargt and N. Blagorazumnga (2005), "HPLC analysis of a new granulated preparation containing isoniazid and pyridoxine hydrochloride", Pharma. Chem., 39,441-443.

6. A. Chimezie, A. lbukun, E. Teddy and F. Onwumere (2008), "HPLC analysis of nicotinamide, pyridoxine, riboflavin and thiamine in some selected food products in nigeria', African J. Pharmacy and Pharmacology, 2, 29-36.

7. B. A. Tangerel, D. Karmarova , Z. Sengee, O. Rop and I. Hoza (2009), "HPLC determination of vitamins $\mathrm{B}_{3}, \mathrm{~B}_{5}$ and $\mathrm{B}_{6}$ in beef liver', Acta Fytotechnica,S,1-7.

8. M. M. Leszek, L. Anne, C. Wojcieh and S. Piotr (2005), "Highperformance liquid chromatography method for the simultaneous determination of thiamine hydrochloride, pyridoxine hydrochloride and cyanocobalamine in pharmaceutical formulations using coulometric electrochemical and ultraviolet detection", $\boldsymbol{J}$. Chromatogr., 1094, 91-98.

9. K. Li (2002), "Simultaneous determination of nicotinamide, pyridoxine hydrochloride, thiamine mononitrate and riboflavin in multivitamin with minerals tablets by reversed-phase ion-pair-high performance liquid chromatography', J, Biomed. Chromatogr., 16,504-507.

10. G. Chen, X. Ding, Z. Cao and J. Ye (2000), "Determination of melatonin and pyridoxine in pharmaceutical preparation for healthcaring purposes by capillary electrophoresis with electrochemical detection", Anal. Chim. Acta,408,249-256.

11. S. F. T. Marcos, M. Gleamed, R. D. Edward and G. T. C. Eder (2004), "Voltametric determination of pyridoxine $\left(\right.$ vitaminB $\left._{6}\right)$ at a carbon paste electrode modified with vanadyl (IV)-salen complex", Anal. Chim. Acta, 508, 79-85.

12. Q. W. Yun, W. K. Bing. And H. S. Shui (2006), "Voltametric determination of pyridoxine (vitamin $\mathrm{B}_{6}$ ) by use of a chemicallymodified glassy carbon electrode", J.Pharm. Biomed.Anal., 43,2-7.

13. P. R. R. Fabio, F. O. Filho and F. R. Boaventura (2003), "A multicommuted flow system for sequential spectrophotometric determination of hydrosoluable vitamins in pharmaceutical preparations", Talanta,59,191-200.

14. J. G. Portela, A. C. S. Costa and L. S. G. Teixeira (2004), "Determination of vitamin $\mathrm{B}_{6}$ in pharmaceutical formulations by flow injection-solid phase spectrophotometry', J. Pharm. Biomed. Anal.,34,543-549.

15. M. Aranda and G. Morlock (2006), "Simultaneous determination of riboflavin, pyridoxine, nicotinamide, caffeine and taurine in energy drunks by planar chromatography-multiple detection with 
confirmation by electrospray ionization mass spectrometry", $\boldsymbol{J}$. Chromatogr. A, 1131, 253-260.

16. A. Pathak, S. J. Raiput (2008), "Simultaneous derivative spectrophotometric analysis of doxylamine succinate, pyridoxine hydrochloride, folic acid in combined dosage forms", Ind. J. Pharm. Sci.,70,513-517.

17. E. din, D. B. leanu and F. onul (2001), "Chemometric quantitative analysis of pyridoxine $\mathrm{HCl}$ and thiamine $\mathrm{HCl}$ in a vitamin combination by principal component analysis, classical least squares, and inverse least squares techniques", Spectrosc. Lett,34,279-288.

18. H. Abdollahi M. H. Sororaddin and A. Naseri (2006), "Simultaneous spectrophotometric determination of piroxicam and pyridoxine using generalized rank annihilation method", Anal. Sci., 22,263.

19. V. Nirmalchandar, R. Viswanathan and N. Balasubramnian (1987)," "Spectrophotometric determination of pyridoxine hydrochloride", Analyst, 112,653-655.

20. K. Srividya and N. Balasabramanian (1997), "Spectrophotometric determination of pyridoxine in pharmaceutical preparation and foods"', J. AOAC International, 80, 1368-1373.

21. A. N. A. Obed-agha (2010), "Development of spectrophotometric, kinetic and chromatographic methods for determination of some drug compounds and aromatic imines" Ph.D. Thesis, MosulUniversity.

22. A. N. Abdulkadir, (2010), "Spectrophotometric determination of vitamin $\mathrm{B}_{6}$ by coupling with diazotized p-nitroaniline", J. Raf. Sci., 21, 49-59.

23. L. M. Pons, L. A. R. Guez, J. E. Romero and M. C. G. A. Coque (1999), "Spectrophotometric determination of $\mathrm{B}_{6}$ vitamins by coupling with diazotized $p$-sulphanilic acid in micellar medium of N-cetylpyridinium chloride"', Anal. Let,32, 51-63.

24. P. Nagaraja and A.K .Shrestha, (2010), " Spectrophotometric method for the determination of drugs containing phenol group by using 2, 4-dinitrophenylhydrazine", $\boldsymbol{E}-\boldsymbol{J}$ of chemistry, 7(2), 395-402.

25. I. Escrig-Tena ; L. A. Rodriguez ; J. Esteve-Romero and M. C. S. Alvarez-Coque (1988), "Micellar modified spectrophotometric determination of nitrobenzene based upon reduction with tin(II), diazotization and coupling with Bration Marthall reagent", Talanta, 47, 43-52 .

26. R. Delevie (1997), "Principle of Quantitative Chemical Analysis ,', Mc Graw-Hill International Edition, Singaapore, p. 498.

27. D. A. Skoog, D. M. West (2004), "Fundamentals of analytical chemistry" $8^{\text {th }}$ edittion, Thomason learning, printed in UnitedState of America, p. 805. 